\title{
"Assessment of the level of financial and economic security at machine-building enterprises: evidence from Ukraine"
}

\begin{tabular}{|c|c|}
\hline \multirow{5}{*}{ AUTHORS } & Alla Cherep (D http://orcid.org/0000-0001-5253-7481 \\
\hline & Dmytro Babmindra (Dttp://orcid.org/0000-0002-1872-3106 \\
\hline & Lina Khudoliei (D http://orcid.org/0000-0003-0910-6816 \\
\hline & Yuliya Kusakova (D http://orcid.org/0000-0002-3827-6972 \\
\hline & $\mathbb{R}$ http://www.researcherid.com/rid/R-1321-2017 \\
\hline ARTICLE INFO & $\begin{array}{l}\text { Alla Cherep, Dmytro Babmindra, Lina Khudoliei and Yuliya Kusakova (2020). } \\
\text { Assessment of the level of financial and economic security at machine-building } \\
\text { enterprises: evidence from Ukraine. Problems and Perspectives in Management, } \\
\text { 18(1), 33-47. doi:10.21511/ppm.18(1).2020.04 }\end{array}$ \\
\hline DOI & http://dx.doi.org/10.21511/ppm.18(1).2020.04 \\
\hline RELEASED ON & Friday, 07 February 2020 \\
\hline RECEIVED ON & Monday, 05 August 2019 \\
\hline \multirow[t]{2}{*}{ ACCEPTED ON } & Friday, 10 January 2020 \\
\hline & $\begin{array}{ll}(\mathrm{cc}) \mathrm{EY} \\
\end{array}$ \\
\hline LICENSE & $\begin{array}{l}\text { This work is licensed under a Creative Commons Attribution } 4.0 \text { International } \\
\text { License }\end{array}$ \\
\hline JOURNAL & "Problems and Perspectives in Management" \\
\hline ISSN PRINT & $1727-7051$ \\
\hline ISSN ONLINE & $1810-5467$ \\
\hline PUBLISHER & LLC "Consulting Publishing Company "Business Perspectives" \\
\hline FOUNDER & LLC "Consulting Publishing Company "Business Perspectives" \\
\hline
\end{tabular}

NUMBER OF REFERENCES

49

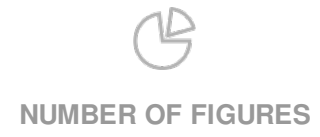

1
NUMBER OF TABLES

9

C The author(s) 2021. This publication is an open access article. 


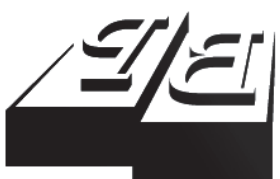

BUSINESS PERSPECTIVES

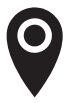

LLC "CPC "Business Perspectives" Hryhorii Skovoroda lane, 10, Sumy, 40022, Ukraine

www.businessperspectives.org

Received on: $5^{\text {th }}$ of August, 2019 Accepted on: $10^{\text {th }}$ of January, 2020

C) Alla Cherep, Dmytro Babmindra, Lina Khudoliei, Yuliya Kusakova, 2020

Alla Cherep, Doctor of Economics, Professor, Dean of the Faculty of Economics, Zaporizhzhya National University, Ukraine.

Dmytro Babmindra, Doctor of Economics, Professor, Head of the Department of International Economics, Natural Resources and Economics of International Tourism, Zaporizhzhya National University, Ukraine.

Lina Khudoliei, Ph.D. in Economics, Senior Lecturer, Department of International Economics, Natural Resources and International Tourism Economics, Zaporizhzhya National University, Ukraine.

Yuliya Kusakova, Ph.D. in Economics, Associate Professor, Department of International Economics, Natural Resources and International Tourism Economics, Zaporizhzhya National University, Ukraine.

\section{(c) (i)}

This is an Open Access article, distributed under the terms of the Creative Commons Attribution 4.0 International license, which permits unrestricted re-use, distribution, and reproduction in any medium, provided the original work is properly cited.

Alla Cherep (Ukraine), Dmytro Babmindra (Ukraine),

Lina Khudoliei (Ukraine), Yuliya Kusakova (Ukraine)

\title{
ASSESSMENT OF THE LEVEL OF FINANCIAL AND ECONOMIC SECURITY AT MACHINE- BUILDING ENTERPRISES: EVIDENCE FROM UKRAINE
}

\begin{abstract}
Determining the level of financial and economic security of an enterprise allows assessing the real possibilities to confront internal and external challenges and defining the potential for future development. To develop proposals on assessing this level, the study uses data on machine-building enterprises of Zaporizhzhia region (Ukraine) and applies integral method, regression analysis and normalization. The expert evaluation method was used to form the system of key parameters. The experts were economists, the accounting departments' and the economic security departments' members of the studied enterprises. The experts selected six indices that they consider to be the most representative of the financial and economic security of an enterprise. These parameters were used to calculate the integral indicator of the level of financial and economic security of enterprises. Harrington's approach was used to group enterprises according to their level of financial and economic security (very high, high, steady, satisfactory and unsatisfactory). The calculations have shown that the integral indicator of financial and economic security of the enterprises of Zaporizhzhia region ranged from 0.32 to 0.66 for the period 2014-2018. It was justified that along with the support of financial stability, solvency, business activity, profitability, investment attractiveness and innovativeness and absent sharp changes in the environment, the level of financial and economic security of machine builders will increase from 0.4 to $11.9 \%$.
\end{abstract}

Keywords

JEL Classification

Acknowledgment(s) The study was carried out within the framework of the state budget theme (state registration number 0117U000512), Establishment of Business Incubators on the Basis of Innovative Development and Ensuring National Financial and Economic Security (2017-2019), Faculty of Economics, Zaporizhzhya National University.

\section{INTRODUCTION}

Deepened international cooperation, both nationally and at the micro level, is accompanied by an increase in external and internal challenges and increased competition. The purpose of an enterprise is not only to survive in the face of uncertainty and risk, but also to achieve a high level of development and enter international markets with competitive products. Therefore, determining the level of the enterprise security is necessary to evaluate the prospects for its development.

The industry in general and the machine-building sector in particular have a strategic impact on the development of any state; this determines its priority in terms of investment attractiveness. The higher 
the level of financial and economic security the enterprises of the industry have, the higher the indicator for the industry as a whole, which determines the stability and prospects for its future development. Therefore, the machine building industry will be more attractive to invest.

Assessing the level of financial and economic security is important for an enterprise, as it reveals its strengths and weaknesses and, based on forecasts, identifies the directions of ensuring adequate financial and economic security.

\section{LITERATURE REVIEW}

Over the last years, in Ukraine, the issue of the enterprise security is increasingly addressed by researchers. An important element of security is its financial and economic component. Therefore, business managers are interested in getting actual data on its level and means of support.

Teneva, Nikolova-Alexieva, and Yaneva (2018) have explored theoretical aspects of financial and economic security in Ukraine. They view economic security as the state, level and prospects for the industrial enterprise development. In view of this, financial and economic security is assessed by constructing a multifactor model and must consider the nature and impact of external factors, on the one hand, and, on the other, the operation of an enterprise in the financial, economic and industrial context under dynamic development of market relations. Only a comprehensive assessment, which includes several common functional components such as financial, technological, intellectual, human, political, legal, and environmental, allows diagnosing the level of financial and economic security of the enterprise. Nikitina and Gorovyi (2017) confirmed the need to consider many factors. They identified main functional components of financial and economic security of an enterprise and argued that the environmental factor significantly affects its financial and economic security.

Sosnovska and Zhytar (2019) have argued that in today's economic realities, achieving the necessary level of financial security of enterprises is a condition for ensuring their sustainable development and competitiveness in the internal and external market environment. The authors propose to systematize the indicators of assessment of the financial security level by its most typical functional components, among which one can distinguish investment, credit, issuing, innovations and currency. The paper indicates that the level of financial and economic security contributes to creating high-quality financial potential, ensuring competitive advantages, harmonizing the interests of economic entities and creating an effective system of financial and economic security of an enterprise. Sustainable development of an enterprise in unstable economic environment is defined as a criterion for the efficiency of ensuring financial and economic security of an enterprise.

Vasilenko and Titova (2019) show the impact of macroeconomic policy on financial and economic security. They point out that the current conditions are driven by constant changes in macroeconomic policies that directly affect the financial and economic performance of economic entities. The economic security of an individual enterprise depends on a properly formulated accounting and taxation policies, as well as counterparty agreements. Iershova, Tkachenko, Garkusha, Miroshnyk, and Novak-Kalyayeva (2019) share this opinion. They proved that the main causes of economic dangers for enterprises are: unstable economic and political situation in the country forcing enterprises to carry out economic activities under risk and uncertainty. This requires the improvement of economic policy, which envisages a symbiosis of the rationality principles and appropriate risk in business activity of enterprises, support of their own financial interests in the market, the desire of enterprises to increase profits and competitive advantages, which directly affect the level of financial and economic security. When analyzing the concept of financial and economic security, scientists have defined it as protection or conservation of entrepreneurial activity to ensure the realization of their own financial interests, optimal use of financial resources, maintaining and growth of profitability and liquidity. Financial and economic security of enterprises is seen as two as- 
pects: protection and state (condition), which includes three components such as financial interests, financial resources and financial condition.

Ganushchak (2017) provides approaches to assessing financial and economic security. The author gives a structural and logical scheme of the procedure for analyzing financial and economic security of an enterprise, characterizes the integral index of financial and economic security, assesses and compares industrial enterprises by the level of their financial and economic security.

Kosny and Piotrowska (2019) have proposed a methodology for assessing the level of financial and economic security based on an analysis of scenarios covering the real-world potential combinations of positive and negative future events, which allows them to assess their impact.

Karanina, Ryazanova, Timin, and Domracheva (2018) analyze the main factors and threats to the financial and economic security of economic entities within certain territories. The system of indicators of financial and economic security assessment of the entities was developed and proposals for diagnostics and risk monitoring were provided.

Hryhoruk, Khrushch, and Grygoruk (2019) analyzed the impact of various threats on the level of financial and economic security of economic entities, which is especially relevant in the context of changing external and internal environment. This requires constant monitoring of the level of financial and economic security to detect and neutralize possible crisis phenomena in a timely manner. The research presents a scientific and methodological approach to developing a composite indicator of financial and economic security and to determining its level.

When considering the problem of assessing the level of financial security, Kondratenko, Kovalenko, and Novikov (2019) use a construction company as an example. They have determined that the specific nature of construction companies and their diverse financial relationships require an appropriate system to protect certain financial interests against existing and potential internal and external threats. Their system of financial and economic security of an enterprise allows selecting factors that influence its level, classifying them and calculating the integral index of financial security. According to these scientists, applying the proposed methodological approach to assessing the level of financial and economic security allows business managers to respond in a timely manner to the deterioration of the entity's financial state and to negative trends that may deepen in the course of the entity operation.

Yaremko, Shykova, and Syvolap (2019) focus on the need to find an effective method for assessing financial and economic security and to identify conceptual and strategic directions for improving the economic security of agricultural enterprises operating in the instable and uncertain environment. To ensure proper economic security of agricultural enterprises, it is proposed to use financial, personnel, legal, information, and organizational tools. The study found that the methodology for assessing the level of economic security consists of two approaches: qualitative and quantitative. The authors systematized indicators for assessing the level of financial and economic security of an agricultural enterprise and substantiated the overall enterprise strategies, which can be used by both agricultural enterprises and enterprises of other industries, according to the level of financial and economic security.

Karpenko and Voronzhak (2017) deal with development of the budget management system at industrial enterprises in terms of the level of financial and economic security. The authors substantiated the need to make sound management decisions of innovative development of enterprises, administrative control over the functioning of the organization within the system of financial and economic security

The concept of economic security has, however, become more widespread, and financial security is seen as its component. Besides, the term of economic security is usually used at the level of state, interstate relations, the world, as well as individuals and families. This can be explained by the origin of the concept, which was first used during the Great Depression in the United States. At that time, the primary task was to protect and secure the assets of individual citizens, which in general affected the socio-economic stability of 
the entire economic system. This approach has then taken root as Anglo-Saxon in the world economic thought. And today, the Aspen Institute Financial Security Program (2019) operates in the United States, whose mission is to illuminate and solve the most critical financial challenges facing American households and to make financial security for all a top national priority. In contrast, Asian economic thought has highlighted the macroeconomic approach.

Tamošiūnienè and Corneliu (2015, July 2-3) (Lithuania and Moldova) clearly identified and characterized these two approaches. They noted that the macro-economic approach had a complex geometry, especially since this period coincides with the time of the two world wars. In particular, it includes Russian school that tried to quantify economic security using critical values, the perspective of national economic vulnerability and capacity for resistance (counteracting the crises and shock absorption).

Representatives of the modern Polish school also follow the macroeconomic approach. Thus, Ignatov (2019) identifies economic security as a condition or state of affairs of a country's socio-economic environment, which is characterized by stable welfare generation supporting the growing living standards. Economic security describes the ability of countries to efficiently implement policies and strategies to reach the desired goals without being constrained by any external or internal threat.

However, Tamošiūnienè and Corneliu (2015, July 2-3) believe that there is a strong need to analyze the concept of economic security broadly taking into consideration both micro- and macroeconomic approaches. Ianioglo and Polajeva (2016) consider economic security from the perspective of enterprise economics. They determine economic security of an enterprise as a state characterized by the ability of the economic entity to ensure taking advantage of resources and opportunities to prevent threats and increase competitive advantages that will allow ensuring stable functioning and development to achieve business goals (2016).

In addition, they analyzed the interpretation of the concept of enterprise economic security and iden- tified the following basic approaches: the state of protection from threats; the state of efficient use of resources; the ability for a stable functioning and development; the presence of competitive advantage; the ability to achieve business goals (Ianioglo \& Polajeva, 2016).

The complex concept of financial and economic security of an enterprise is used by Ukrainian, Russian, Byelorussian, Moldovan, Kazakh and other scientists from post-Soviet countries. This can be due to considerable business sector vulnerability in these countries to the financial and economic crises that have intensified since the collapse of the USSR.

Stolbov and Shapoval (2013) define financial and economic security of an enterprise as protection of its resources and intellectual capacity from the existing and potential threats of the external and internal environment, which is characterized by high financial performance and the prospect for economic development in the future.

Moiseienko and Marchenko (2011) consider financial and economic security as a condition that ensures protection of its financial and economic interests from internal and external threats and creates necessary financial and economic preconditions for sustainable development in the current and long-term periods.

Arefieva and Kuzenko (2009) believe that financial and economic security can be defined as the most effective use of corporate resources of an enterprise, expressed in the best values of financial indicators of profitability and cost-effectiveness of business, management quality, the use of fixed and current assets, the structure of its capital, the rate of payment on the enterprise's securities, as well as the exchange rate of its securities as a synthetic indicator of the current financial and economic condition of an enterprise and prospects for its technological and financial development.

Kyrychenko and Kudria (2009) define financial security of an enterprise as activities on risk management and protection of the enterprise interests against external and internal threats to ensure its stable development and growth of its capital in the current and strategic perspectives. 
Kudrytska (2012) believe that the financial and economic security of an enterprise should be considered as a balanced state of its elements and subsystems as a separate economic system; the elements can be expressed as quantitative or qualitative indicators and characterized by resistance to negative internal and external influences and by the ability to ensure its effective functioning, sustainable development, and economic growth.

Mulyk (2013) defines the financial security of an enterprise as protection of its financial interests at all levels of financial relations from the influence of external and internal threats, which ensures its self-preservation and development in the current and strategic perspectives.

Kriuchko (2013) defines financial security as an entity's ability to effectively and steadily carry out its economic activities, including financial activities, by using a set of interrelated diagnostic, instrumental and control financial measures that should optimize the use of financial resources, ensure their proper level and mitigate internal and external effects.

An analysis of the above definitions suggests that many authors combine different approaches. Besides, there is no particular distinction between financial security and financial and economic security. However, the approaches of Ianioglo and Polajeva can be extended by treating financial and economic security as a risk management activity and protecting the interests of the enterprise. This study also considers it necessary to combine all key interpretations as one definition; this will allow presenting the concept in the most comprehensive way and revealing its essence.

Therefore, this study considers the financial and economic security as the ability of an entity to effectively manage its resources and the benefits available to minimize risks, protect against external and internal threats, and uphold personal interests, which will ensure the stable operation, development and implementation of strategic guidelines.

Over the last decade, financial and economic security has become a widespread issue. For example, Vergun, Nefedova, and Tarasenko (2015) suggested the stages of managing the financial and economic security of an enterprise.
Onishchenko and Siurkalo (2018), Vasilyev and Maita (2013), Kovalenko and Lehka (2015) propose mechanisms for managing financial and economic security of enterprises.

Cherniak (2015), Bondarenko and Levytskyy (2015), Korniienko (2013) and others analyze the methods to evaluate financial and economic security of an enterprise.

Determining the performance efficiency and the value of the enterprises, investigated by Young and O'Byrne (2000) and Lewis (2006), remains a problem area. Analysis of articles by Roe (2012), Thompson (2009), Haralambides (2002) and others for the years 2002-2018 indicates that many authors explored the methods for assessing the level of enterprise competitiveness.

In developed countries, many scientific and professional journals also pay special attention to the following issues: protecting businesses from all kinds of threats; use of truthful, reliable and timely information; identifying strengths and weaknesses to ensure their viability (Giannopoulos, Filippini, \& Schimmer, 2012; Vercellis, 2009). Calof $(2015,2016)$, Prescott (1990), du Toit (2015) and others are the leaders in the number of publications assessing both the level of competitiveness and the value of enterprises.

Despite the multifaceted nature of the issues already addressed, it is worth noting that there is no single, systematic approach to assessing the financial and economic security of enterprises, which would allow economic entities not only to adjust the indicators of financial and economic security and to determine the factors influencing their reduction, but also to become competitive in the market and increase the possibility of innovative investment development in the future. It is advisable to improve the methodology for assessing the level of financial and economic security of enterprises.

\section{AIMS}

The purpose of the paper is to assess the level of financial and economic security of enterprises, as well as its further forecasting, which will help to identify key areas of management policy. 


\section{METHODS}

To assess the level of financial and economic security, enterprises of the machine-building industry were selected, which is promising in terms of attractiveness for internal and external investors and ensuring the competitiveness of the economy, and is also sensitive to changes in the external environment.

The financial and economic security of the enterprise $(\mathrm{Y})$ is estimated based on the values of generalized groups of indicators (factors) (Table 1).

Table 1. Generalized indicators (factors) of financial and economic security

Source: Authors.

\begin{tabular}{|c|c|}
\hline Group & Indicators, $x_{i}$ \\
\hline \multirow{5}{*}{$\begin{array}{l}\text { Group integral } \\
\text { indicators of financial } \\
\text { sustainability }\left(I_{F S}\right)\end{array}$} & Economic growth sustainability ratio \\
\hline & Loan capital concentration ratio \\
\hline & Financial sustainability (funding) ratio \\
\hline & Financial autonomy ratio \\
\hline & Equity maneuverability ratio \\
\hline \multirow{4}{*}{$\begin{array}{l}\text { Group integral } \\
\text { indicators of liquidity } \\
\text { and solvency }\left(I_{s}\right)\end{array}$} & Absolute liquidity ratio \\
\hline & Current ratio \\
\hline & Quick liquidity ratio \\
\hline & Overall liquidity ratio \\
\hline \multirow{3}{*}{$\begin{array}{l}\text { Group integral } \\
\text { indicators of business } \\
\text { sentiment }\left(I_{B S}\right)\end{array}$} & Equity turnover \\
\hline & Asset turnover ratio \\
\hline & Receivables turnover ratio \\
\hline \multirow{7}{*}{$\begin{array}{l}\text { Group integral } \\
\text { profitability } \\
\text { indicators }\left(I_{P}\right)\end{array}$} & Return on assets ratio \\
\hline & Return on equity ratio \\
\hline & Return on production assets \\
\hline & Return on sales \\
\hline & Net operating margin \\
\hline & Net Profit Margin \\
\hline & Economic growth sustainability ratio \\
\hline \multirow{3}{*}{$\begin{array}{l}\text { Group integral } \\
\text { indicators of investment } \\
\text { attractiveness }\left(I_{I A}\right)\end{array}$} & Investment ratio \\
\hline & Return on Investment \\
\hline & Investment coverage ratio \\
\hline \multirow{3}{*}{$\begin{array}{l}\text { Group integral } \\
\text { indicators of innovative } \\
\text { development }\left(I_{I D}\right)\end{array}$} & Innovation rate \\
\hline & Innovation-intensive ratio \\
\hline & $R \& D$ performance ratio \\
\hline
\end{tabular}

The indicators are grouped based on expert assessments by means of questionnaires, the result of which is the determining key indicators of financial and economic security. The values of the relevant indicators are derived from the analysis of the enterprises' statistical reporting. The expert evaluation method was used to form the key metrics system. 16 economists, 24 accounting depart- ment members and 12 economic security department employees act as experts. They all worked at Zaporizhzhia Mechanical Plant, Zaporozhye Heavy Crane-Building Plant, Berdianski Zhnyvarky, and Energomash-Project Research and Production Enterprise. A questionnaire was developed for them and they were asked to be interviewed. The questionnaire specified indicators describing the financial and economic situation of the enterprise. Experts selected six of the proposed indicators, which, in their opinion, most described financial and economic security of an enterprise. These indicators were used to calculate the integral indicator of financial and economic security of enterprises under study.

For further analysis, it is necessary to standardize the selected indicators of financial and economic security. Two indicator groups were chosen: incentives that help to increase economic security and disincentives that reduce economic security.

Having calculated the normalized values of financial and economic security indicators, the significance of individual indicators for each group and for the whole was determined. It should be noted that the development strategies of the surveyed enterprises assume the same level of significance of each indicator and, accordingly, the same impact on the integral indicator for the group:

$$
r_{j i}=\frac{1}{M}, \quad i=1, N, j=1, M
$$

Weighting coefficients were used to determine the significance of the indicators. To determine the group weights, the Fishburn's rule (1978) was used, which provides for the significance level of indicator groups in the form of interval estimates, i.e.,

$$
a_{i} \leq w_{i} \leq b_{i}, i=\overline{1, m} .
$$

To calculate the group integral financial and economic security indicators, the Harrington's (1965) desirability function is used, which is a quantitative measure of the studied entity's quality.

Based on Harrington's approach, enterprises are grouped according to their levels of financial and economic security (very high, high, steady, satisfactory and unsatisfactory). 


\section{RESULTS}

The proposed approach was implemented at the machine-building enterprises of Zaporizhzhia region (Zaporizhzhia Mechanical Plant, Zaporozhye Heavy Crane-Building Plant (Zaporozhcran), Berdianski Zhnyvarky, and Energomash-Project Research and Production Enterprise) according to the following algorithm:

Step 1: Analyze the statistical reporting of enterprises and systematize necessary information.

Step 2: Identify key financial and economic security indicators based on expert estimates.

Step 3: Normalize incentives and disincentives.

Step 4: Calculate the indicators' significance based on Fishburn's weights and determine interval weights.

Step 5: Group companies by their level of financial and economic security based on the Harrington's desirability function.

Step 6: Forecast the activity of the machine-building enterprises depending on the level of financial and economic security based on regression analysis.

Based on the analysis of the machine-building enterprises' statistical reporting, the necessary information has been systematized. Indicators were grouped on the basis of expert assessments, which were obtained based on a survey of management and financial and economic department representatives of machine-building enterprises in Zaporizhzhia region. This choice is due to the fact that these employees directly receive information on the results of their enterprise economic activity and determine the directions for further actions and management methods. The questionnaire identified key indicators of financial and economic security that characterize its essence, namely: indicators of financial strength; liquidity and solvency indicators; business activity indicators; profitability indicators; indicators of innovative development; and investment attractiveness indicators.
According to the strategic benchmarks and the main goals of the enterprises' activity, the possible intervals of their importance for each indicator group are determined:

$$
\begin{aligned}
& w_{1} \in[0.281 ; 0.554] ; w_{1} \in[0.281 ; 0.554] ; \\
& w_{2} \in[0.201 ; 0.471] ; w_{2} \in[0.201 ; 0.471] ; \\
& w_{3} \in[0.155 ; 0.387] ; w_{3} \in[0.155 ; 0.387] ; \\
& w_{4} \in[0.187 ; 0.466] ; w_{4} \in[0.187 ; 0.466] ; \\
& w_{5} \in[0.165 ; 0.401] ; w_{5} \in[0.165 ; 0.401] ; \\
& w_{6} \in[0.133 ; 0.298] ; w_{6} \in[0.133 ; 0.298]
\end{aligned}
$$

Weighting parameters were calculated according to the Fishburn's rule (1978):

$$
\begin{aligned}
& a_{i} a_{i}=0.281+0.201+0.155+ \\
& +0.187+0.165+0.133=1.1 \\
& b_{i} b_{i}=0.554+0.471+0.387+ \\
& +0.466+0.401+0.298 \\
& \left(b_{i}-a_{i} b_{i}-a_{i}\right)=(0.554-0.281)+\ldots \\
& \ldots+(0.298-0.133)=1.455
\end{aligned}
$$

The weighting parameters for each group will be as follows:

$$
\begin{aligned}
& w_{1} w_{1}=0.281+\frac{1-1.1}{1.455} \cdot 0.273=0.258 \\
& w_{2} w_{2}=0.201+\frac{1-1.1}{1.455} \cdot 0.27=0.178 \\
& w_{3} w_{3}=0.155+\frac{1-1.1}{1.455} \cdot 0.232=0.136 \\
& w_{4} w_{4}=0.187+\frac{1-1.1}{1.455} \cdot 0.279=0.164 \\
& w_{5} w_{5}=0.165+\frac{1-1.1}{1.455} \cdot 0.236=0.145 \\
& w_{6} w_{6}=0.133+\frac{1-1.1}{1.455} \cdot 0.165=0.116
\end{aligned}
$$

The following condition is fulfilled: the sum of

$$
\begin{aligned}
& w_{i} w_{i}=0.258+0.178+0.136+ \\
& +0.164+0.145+0.119=1 .
\end{aligned}
$$


Thus, the weighting coefficients were obtained for each individual value of the financial ratios and the groups were formed (Table 2). The weight of the indicator of each individual group was set the same for each coefficient.

Table 2. Weighting coefficients of financial and economic security indicators' groups

\begin{tabular}{|c|c|c|c|}
\hline Group & $\begin{array}{c}\text { Weight } \\
\text { of } \\
\text { a group }\end{array}$ & Indicators, $x_{i} x_{i}$ & $\begin{array}{l}\text { Weight } \\
\text { of an } \\
\text { indicator }\end{array}$ \\
\hline \multirow{5}{*}{$\begin{array}{l}\text { Group integral } \\
\text { indicators } \\
\text { of financial } \\
\text { sustainability } \\
\left(I_{F S}\right)\end{array}$} & \multirow{5}{*}{0.258} & $\begin{array}{l}\text { Economic growth } \\
\text { sustainability ratio }\end{array}$ & 0.2 \\
\hline & & $\begin{array}{c}\text { Loan capital } \\
\text { concentration ratio }\end{array}$ & 0.2 \\
\hline & & $\begin{array}{l}\text { Financial sustainability } \\
\text { (funding) ratio }\end{array}$ & 0.2 \\
\hline & & $\begin{array}{l}\text { Financial autonomy } \\
\text { ratio }\end{array}$ & 0.2 \\
\hline & & $\begin{array}{l}\text { Equity maneuverability } \\
\text { ratio }\end{array}$ & 0.2 \\
\hline \multirow{4}{*}{$\begin{array}{l}\text { Group integral } \\
\text { indicators of } \\
\text { liquidity and } \\
\text { solvency }\left(I_{s}\right)\end{array}$} & \multirow{4}{*}{0.178} & Absolute liquidity ratio & 0.333 \\
\hline & & Current ratio & 0.333 \\
\hline & & Quick liquidity ratio & 0.333 \\
\hline & & Overall liquidity ratio & 0.333 \\
\hline \multirow{3}{*}{$\begin{array}{l}\text { Group integral } \\
\text { indicators } \\
\text { of business } \\
\text { sentiment }\left(I_{B S}\right)\end{array}$} & \multirow{3}{*}{0.136} & Equity turnover & 0.333 \\
\hline & & Asset turnover ratio & 0.333 \\
\hline & & $\begin{array}{c}\text { Receivables turnover } \\
\text { ratio }\end{array}$ & 0.333 \\
\hline \multirow{7}{*}{$\begin{array}{l}\text { Group integral } \\
\text { profitability } \\
\text { indicators }\left(I_{p}\right)\end{array}$} & \multirow{7}{*}{0.164} & Return on assets ratio & 0.143 \\
\hline & & Return on equity ratio & 0.143 \\
\hline & & $\begin{array}{c}\text { Return on production } \\
\text { assets }\end{array}$ & 0.143 \\
\hline & & Return on sales & 0.143 \\
\hline & & Net operating margin & 0.143 \\
\hline & & Net Profit Margin & 0.143 \\
\hline & & $\begin{array}{l}\text { Economic growth } \\
\text { sustainability ratio }\end{array}$ & 0.143 \\
\hline \multirow{3}{*}{$\begin{array}{l}\text { Group integral } \\
\text { indicators of } \\
\text { investment } \\
\text { attractiveness } \\
\left(I_{I A}\right)\end{array}$} & \multirow[b]{3}{*}{0.145} & Investment ratio & 0.333 \\
\hline & & Return on Investment & 0.333 \\
\hline & & $\begin{array}{l}\text { Investment coverage } \\
\text { ratio }\end{array}$ & 0.333 \\
\hline \multirow{3}{*}{$\begin{array}{l}\text { Group integral } \\
\text { indicators of } \\
\text { innovative } \\
\text { development }\left(I_{I D}\right)\end{array}$} & \multirow{3}{*}{0.119} & Innovation rate & 0.333 \\
\hline & & $\begin{array}{c}\text { Innovation-intensive } \\
\text { ratio }\end{array}$ & 0.333 \\
\hline & & R\&D performance ratio & 0.333 \\
\hline
\end{tabular}

Table 3 presents the calculations of group integrated indicators of financial and economic security of enterprises.
Table 3. Group integral indicators of the studied enterprises

Source: Calculated by the authors based on the official websites of Energomash-Project Research and Production Enterprise, Berdianski Zhnyvarky, Zaporozhye Heavy Crane-Building Plant, and Zaporizhzhia Mechanical Plant.

\begin{tabular}{|c|c|c|c|c|c|}
\hline \multirow{2}{*}{$\begin{array}{l}\text { Group integral } \\
\text { indicators }\end{array}$} & \multicolumn{5}{|c|}{ Years } \\
\hline & 2014 & 2015 & 2016 & 2017 & 2018 \\
\hline
\end{tabular}
Zaporizhzhia Mechanical Plant

\begin{tabular}{l:l:l:l:l:l}
\hline Profitability indicators & 0.387 & 0.386 & 0.378 & 0.377 & 0.378 \\
\hdashline $\begin{array}{l}\text { Indicators of financial } \\
\text { sustainability }\end{array}$ & 0.381 & 0.402 & 0.381 & 0.383 & 0.401 \\
\hline $\begin{array}{l}\text { Indicators of liquidity and } \\
\text { solvency }\end{array}$ & 0.401 & 0.396 & 0.403 & 0.388 & 0.396 \\
\hline $\begin{array}{l}\text { Indicators of innovative } \\
\text { development }\end{array}$ & 0.392 & 0.389 & 0.385 & 0.382 & 0.401 \\
\hline $\begin{array}{l}\text { Indicators of investment } \\
\text { attractiveness }\end{array}$ & 0.381 & 0.386 & 0.387 & 0.392 & 0.376 \\
\hline $\begin{array}{l}\text { Indicators of business } \\
\text { sentiment }\end{array}$ & 0.389 & 0.391 & 0.397 & 0.388 & 0.394 \\
\hline
\end{tabular}
sentiment

\section{Zaporozhye Heavy Crane-Building Plant}

\begin{tabular}{ll:l:l|l|l|l}
\hline Profitability indicators & 0.392 & 0.401 & 0.391 & 0.387 & 0.398
\end{tabular}

Indicators of financial sustainability

Indicators of liquidity and $\quad 0.358: 0.391: 0.389: 0.388: 0.405$ solvency

Indicators of innovative

development

Indicators of investment

attractiveness

Indicators of business

sentiment

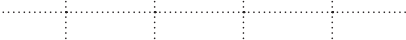

\begin{tabular}{l|l|l|l|l}
0.392 & 0.345 & 0.374 & 0.381 & 0.384
\end{tabular}

\begin{tabular}{l|l|l|l|l}
0.381 & 0.39 & 0.372 & 0.373 & 0.383
\end{tabular}

$0.401: 0.396: 0.389: 0.385: 0.393$

Berdianski Zhnyvarky

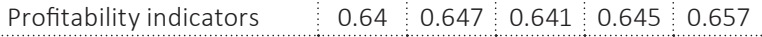

Indicators of financial

\begin{tabular}{l|l:l:l:l:l} 
sustainability & 0.623 & 0.651 & 0.679 & 0.58 & 0.632
\end{tabular}

Indicators of liquidity and $\quad \begin{array}{lll:lll:l} & 0.656 & 0.688 & 0.701 & 0.7 & 0.702\end{array}$

solvency

Indicators of innovative $\quad$ o.643 $0.682: 0.675: 0.671: 0.679$

development

Indicators of investment

attractiveness

\begin{tabular}{l|l:l:l:l}
0.641 & 0.658 & 0.649 & 0.648 & 0.657
\end{tabular}

Indicators of business

sentiment

\begin{tabular}{l|l|l|l|l}
0.646 & 0.671 & 0.659 & 0.662 & 0.656
\end{tabular}

\section{Energomash-Project Research}

and Production Enterprise

\begin{tabular}{ll|l|l|l|l|l}
\hline Profitability indicators & 0.331 & 0.258 & 0.247 & 0.379 & 0.375
\end{tabular}

\begin{tabular}{ll|l|l|l|l}
0.341 & 0.379 & 0.381 & 0.375 & 0.382
\end{tabular}

sustainability

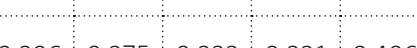

dicators of liquidity and

solvency

Indicators of innovative

development

Indicators of investment

attractiveness

Indicators of business

sentiment

\begin{tabular}{l:l|l:l:l}
0.321 & 0.369 & 0.372 & 0.389 & 0.389
\end{tabular}

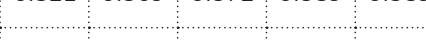

\begin{tabular}{ll|l|l|l|l}
0.323 & 0.369 & 0.38 & 0.381 & 0.379
\end{tabular}

$\begin{array}{l:l:l:l:l}0.32 & 0.367 & 0.369 & 0.369 & 0.373\end{array}$

Thus, based on the proposed methodology, a regression model of the financial and economic security assessment of the enterprise was constructed: 
$I_{F S}=0.258 I_{F S}+0.178 I_{S}+0.136 I_{B S}+$ $+0.164 I_{P}+0.145 I_{I A}+0.119 I_{I D}$,

where $I_{F S}$ - general integral indicator of financial and economic security, $I_{F S}$ - group integral indicator of financial strength, $I_{S}$ - group integral solvency indicator, $I_{B S}$ - group integral indicator of business activity, $I_{P}$ - group integral profitability indicator, $I_{I A}$ - group integral indicator of investment attractiveness, $I_{I D}$ - group integral indicator of innovative development.

Based on the constructed model, general integral financial and economic security indicators for the studied enterprises are calculated and the levels of their financial and economic security are determined.

To define the level of financial and economic security, Harrington's desirability function is used. The Harrington's desirability function is roughly divided into five levels that correspond to the aforementioned variables of financial and economic security and characterize the dimensionless value of indicators. The coordinate point $(0.00$; 0.37 ) is a critical point that divides the indicator scale into two groups: satisfactory and unsatisfactory (Table 4 ).

Table 4. Classification of the levels of business financial and economic security

\begin{tabular}{c:c} 
& Source: Calculated by the authors based on Harrington (1965). \\
\hline $\begin{array}{c}\text { Index } \\
\text { value }\end{array}$ & $\begin{array}{c}\text { Characteristics of business financial } \\
\text { and economic security level }\end{array}$ \\
\hline $1.00-0.81$ & Too high level of financial and economic security (TH) \\
\hdashline $0.80-0.64$ & High level of financial and economic security (H)
\end{tabular}

Interval assessment of indicators characterizing the level of financial and economic security is as follows:

1. $0.00-0.20$ - unsatisfactory level of financial and economic security (US), when an enterprise has low solvency and financial stability, conducts loss-making activity and is dependent on external sources of financing. The company is unable to meet its financial obligations and may be on the verge of bankruptcy;
2. 0.37-0.21 - satisfactory level of financial and economic security (S), a situation whereby an enterprise has an unstable capital structure, insufficient liquidity and uses its capital ineffectively. The enterprise attracts short-term loans to ensure its financing;

3. $0.63-0.38$ - steady level of financial and economic security (St) - indicators describing the level of financial and economic security are within the recommended values;

4. 0.80-0.64 - high level of financial and economic security $(\mathrm{H})$, the enterprise has a plentiful supply of competitiveness and is characterized by high financial stability;

5. 1.00-0.81 - too high level of financial and economic security $(\mathrm{TH})$ - the enterprise has an extremely high level of solvency and profitability and conducts effective financial and economic activity.

Let us calculate the general integral indicators of financial and economic security of machine-building enterprises in Zaporizhzhia region and define the change in their financial and economic security (Table 5).

Table 5. General integral indicators of financial and economic security of mechanical engineering enterprises of Zaporizhzhia region, 2014-2018

Source: Calculated by the authors based on the official websites of Energomash-Project Research and Production Enterprise, Berdianski Zhnyvarky, Zaporozhye Heavy Crane-Building Plant, and Zaporizhzhia Mechanical Plant.

\begin{tabular}{|c|c|c|c|c|c|c|}
\hline \multirow{2}{*}{ No. } & \multirow{2}{*}{ Enterprise } & \multicolumn{5}{|c|}{ Period } \\
\hline & & 2014 & 2015 & 2016 & 2017 & 2018 \\
\hline \multirow{2}{*}{1} & \multirow{2}{*}{$\begin{array}{l}\text { Zaporizhzhia } \\
\text { Mechanical Plant }\end{array}$} & 0.388 & 0.391 & 0.387 & 0.384 & 0.390 \\
\hline & & St & St & St & St & St \\
\hline \multirow{2}{*}{2} & \multirow{2}{*}{$\begin{array}{l}\text { Zaporozhye Heavy } \\
\text { Crane-Building Plant }\end{array}$} & 0.385 & 0.384 & 0.382 & 0.382 & 0.390 \\
\hline & & St & St & St & St & St \\
\hline \multirow{2}{*}{3} & \multirow{2}{*}{ Berdianski Zhnyvarky } & 0.64 & 0.66 & 0.66 & 0.64 & 0.66 \\
\hline & & St & $\mathrm{H}$ & $\mathrm{H}$ & St & $\mathrm{H}$ \\
\hline \multirow[b]{2}{*}{4} & \multirow{2}{*}{$\begin{array}{l}\text { Energomash-Project } \\
\text { Research and } \\
\text { Production Enterprise }\end{array}$} & 0.32 & 0.33 & 0.34 & 0.37 & 0.38 \\
\hline & & $\mathrm{S}$ & S & S & St & St \\
\hline
\end{tabular}

Table 5 shows that in 2014-2018, the surveyed enterprises had high $(\mathrm{H})$ or steady $(\mathrm{St})$ level of financial and economic security. Only EnergomashProject Research and Production Enterprise LLC 
had a satisfactory level of financial and economic security (S) in 2014-2016, which is due to low values of financial strength, business activity and innovation development.

Given the regression model based on the values of the general integral indicator of machine-builder's financial and economic security in Zaporizhzhia region, a forecast of the financial security level will be made.

The forecasting involves the following steps:

Step 1: Selecting group indicators to build regression models.

Step 2: Building additive and multiplicative regression models and selecting the optimal model.

Step 3: Assessing the regression modeling adequacy and interpreting the results.

Step 4: Calculating the annual and average annual growth rates of the group indicators included in the regression models and determining the targets.

Step 5: Forecasting the general integral financial and economic security indicator of Zaporizhzhia region machine-building enterprises by 2020 .

Step 1. The group integral and general integral indicators of financial and economic security of the machine-building enterprises in Zaporizhzhia region are the basis for forecasting. However, due to the analysis of key metrics over the last five years, the study cannot use all six metrics to construct regression models.

According to the general methodology, two or three group indicators are indicative. Correlation analysis is used to select the required metrics. Table 6 presents the results.

As Table 6 shows, for almost every enterprise, it is possible to identify highly significant group financial and economic security indicators that can be further used to construct regression models. However, for the Zaporozhye Heavy Crane-Building Plant, all the group indicators analyzed were of medium significance (correlation coefficients from 0.25 to 0.64 ). In this case, the study selects indicators that are jointly significant in the regression models (group integral indicators of financial stability and solvency were chosen). Similarly, other business metrics were tested for consistent significance in the regression. It is found that for Zaporizhzhia Mechanical Plant, the group integral indicator of innovative development loses its significance along with the group integral financial stability index; it is replaced, therefore, by group integral indicators of business activity and solvency. For the Berdianski Zhnyvarky company, the regression model uses the group integral indicators of financial strength, profitability and innovative development as the most significant and demonstrative ones. For Energomash-Project Research and Production Enterprise, highly significant group solvency and innovation development indicators, when combined into a single model, supplant one another, so medium-significant group financial strength and profitability integral indicators are chosen for modeling.

Table 6. Correlation and regression analysis of group indicators of business financial and economic security

\begin{tabular}{|c|c|c|c|}
\hline Enterprise & High value indicators & $\begin{array}{l}\text { Multicollinearity indicators } \\
\text { one by one }\end{array}$ & $\begin{array}{l}\text { Indicators applied } \\
\text { for forecasting }\end{array}$ \\
\hline Zaporizhzhia Mechanical Plant & $I_{F S}$ and $I_{I D}$ & None & $I_{F S^{\prime}} I_{S}$ and $I_{B S}$ \\
\hline $\begin{array}{l}\text { Zaporozhye Heavy Crane-Building } \\
\text { Plant }\end{array}$ & none & $I_{I A}$ and $I_{P} ; I_{F S}$ and $I_{B S}$ & $I_{F S}$ and $I_{S}$ \\
\hline Berdianski Zhnyvarky & $I_{F S^{\prime}} I_{I A}$ and $I_{I D}$ & $\begin{array}{c}I_{I A} \text { and } I_{P} ; I_{S} \text { and } I_{I D} ; I_{I D} \text { and } I_{I A} ; I_{B S} \text { and } \\
I_{I D} ; I_{B S} \text { and } I_{I A}\end{array}$ & $I_{P}, I_{F S}$ and $I_{I D}$ \\
\hline $\begin{array}{l}\text { Energomash-Project Research and } \\
\text { Production Enterprise }\end{array}$ & $I_{S}$, and $I_{I D}$ & $\begin{array}{c}I_{F S} \text { and } I_{I D} ; I_{F S} \text { and } I_{I A} ; I_{F S} \text { and } I_{B S} ; I_{I A} \text { and } \\
I_{I D} ; I_{B S} \text { and } I_{I D} ; I_{B S} \text { and } I_{I A}\end{array}$ & $I_{S}$ and $I_{F S}$ \\
\hline
\end{tabular}


Table 7. Types of mathematical correlation between general integral indicator of business financial and economic security and the selected group indicators

Source: Calculated by the authors.

\begin{tabular}{|c|c|c|c|c|}
\hline \multirow[b]{2}{*}{$\begin{array}{c}\text { Type of } \\
\text { correlation }\end{array}$} & \multicolumn{4}{|c|}{$R^{2}$ of the models of the integral indicator of financial and economic security } \\
\hline & $\begin{array}{c}\text { Zaporizhzhia } \\
\text { Mechanical Plant }\end{array}$ & $\begin{array}{l}\text { Zaporozhye Heavy } \\
\text { Crane-Building Plant }\end{array}$ & $\begin{array}{l}\text { Berdianski } \\
\text { Zhnyvarky }\end{array}$ & $\begin{array}{c}\text { Energomash-Project } \\
\text { Research and Production } \\
\text { Enterprise }\end{array}$ \\
\hline Linear & 0.999841 & 0.912939 & 0.998764 & 0.972452 \\
\hline Stepwise & 0.999834 & 0.908271 & 0.999345 & 0.968152 \\
\hline Exponential & 0.999865 & 0.913285 & 0.998764 & 0.971849 \\
\hline Hyperbolic & 0.999771 & 0.902740 & 0.999722 & 0.964387 \\
\hline Quadratic & 0.999873 & 0.917843 & 0.997945 & 0.975131 \\
\hline Logarithmic & 0.999808 & 0.907901 & 0.999345 & 0.968906 \\
\hline Root & 0.999825 & 0.910436 & 0.999082 & 0.970794 \\
\hline
\end{tabular}

Step 2. This step chooses the type of relationship between the general integral indicator of financial and economic security of an enterprise and its components. For this purpose, linear, stepwise, exponential, hyperbolic, quadratic, logarithmic and root regressions are calculated (Table 7). Given the determination coefficient (R2), the model is selected that best describes the dependency. For Zaporizhzhia Mechanical Plant, Zaporozhye Heavy Crane-Building Plant and Energomash-Project Research and Production Enterprise, it is quadratic model, and it is hyperbolic for Berdianski Zhnyvarky.

Step 3. Having chosen the dependence type, let us evaluate the adequacy of the regression models by the determination indicators and the Fisher test. All determination coefficients exceed 0.8 , which indicates the model's visibility. Fisher's criterion $(\mathrm{F})$ is an F-statistic whose value exceeds the table value; besides, all models are significant. Thus, the models can be considered adequate and indicative (Table 8).

Thus, models for Zaporizhzhia Mechanical Plant, Zaporozhye Heavy Crane-Building Plant,
Energomash-Project Research and Production Enterprise, and Berdianski Zhnyvarky demonstrate a direct relationship between the growth of group indicators of financial strength, solvency, profitability, and innovative development and an integral financial and economic security indicator. This is logical and does not need further clarification. One can observe only one inverse relationship: for Zaporizhzhia Mechanical Plant, the increase in the group business activity index causes a reduction in the integral indicator of financial and economic security. This is due to the increased uncertainty and risk related to the increase in the number of contractors, the volume of transactions and the sale of products. The strength of the relationship between the analyzed metrics for each enterprise is different and is defined by the significance coefficients.

Step 4. Determining the annual and average annual growth rates of the group integral indicators included in the regression models (Table 9). Suppose that the overall tendency for group integral indicators to fluctuate for two years is maintained. Substantial changes in the near term can only happen under the influence of external

Table 8. The models of correlation between the integral indicator of business financial and economic security and its components

Source: Developed by the authors.

\begin{tabular}{|c|c|c|c|}
\hline Enterprises & Linear-regression model & $R$-squared & F-statistics \\
\hline Zaporizhzhia Mechanical Plant & $I_{F S}^{1}=0.311+0.317 \cdot I_{F S}^{2}+0.461 \cdot I_{S}^{1}-0.282 \cdot I_{B S}^{1}$ & 0.99 & 18.84 \\
\hline $\begin{array}{l}\text { Zaporozhye Heavy Crane-Building } \\
\text { Plant }\end{array}$ & $I_{F S}^{2}=0.125+1.594 \cdot I_{F S}^{2}+0.2 \cdot I_{S}^{1}$ & 0.92 & 11.17 \\
\hline Berdianski Zhnyvarky & $I_{F S}^{3}=1.289-\frac{0.213}{I_{P}}-\frac{0.084}{I_{F S}}-\frac{0.116}{I_{I A}}$ & 0.99 & 11.30 \\
\hline $\begin{array}{l}\text { Energomash-Project Research and } \\
\text { Production Enterprise }\end{array}$ & $I_{F S}^{4}=0.096+0.526 \cdot I_{P}^{2}+1.426 \cdot I_{F S}^{2}$ & 0.98 & 36.55 \\
\hline
\end{tabular}


Table 9. Calculation of annual average growth rates of group integral indicators and their projected values

\begin{tabular}{|c|c|c|c|c|c|c|c|c|}
\hline \multirow[t]{2}{*}{ Enterprise } & \multirow{2}{*}{$\begin{array}{l}\text { Group } \\
\text { indicators }\end{array}$} & \multicolumn{4}{|c|}{ Growth (loss) rates } & \multirow{2}{*}{$\begin{array}{l}\text { Annual } \\
\text { average } \\
\text { growth }\end{array}$} & \multicolumn{2}{|c|}{$\begin{array}{l}\text { Projected group } \\
\text { indicators' values }\end{array}$} \\
\hline & & $2015 / 2014$ & $2016 / 2015$ & $2017 / 2016$ & 2018/2017 & & 2019 & 2020 \\
\hline \multirow{3}{*}{$\begin{array}{l}\text { Zaporizhzhia Mechanical } \\
\text { Plant }\end{array}$} & $I_{E S \ldots}$ & 1.055 & 0.948 & 1.005 & 1.047 & 1.014 & 0.407 & 0.412 \\
\hline & $I_{s}$ & 0.988 & 1.018 & 0.963 & 1.021 & 0.997 & 0.395 & 0.394 \\
\hline & $\mathrm{I}_{\mathrm{BS} \ldots}$ & 1.005 & 1.015 & 0.977 & 1.015 & 1.003 & 0.395 & 0.397 \\
\hline \multirow{2}{*}{$\begin{array}{l}\text { Zaporozhye Heavy } \\
\text { Crane-Building Plant }\end{array}$} & $\mathrm{I}_{\mathrm{FS}}$ & 0.990 & 0.992 & 1.005 & 1.008 & 0.999 & 0.381 & 0.380 \\
\hline & $I_{5}$ & 1.092 & 0.995 & 0.997 & 1.044 & 1.032 & 0.418 & 0.432 \\
\hline \multirow{3}{*}{ Berdianski Zhnyvarky } & $I_{p}$ & 1.011 & 0.991 & 1.006 & 1.019 & 1.007 & 0.661 & 0.666 \\
\hline & $\mathrm{I}_{\mathrm{FS}} \ldots$ & 1.045 & 1.043 & 0.854 & 1.090 & 1.008 & 0.637 & 0.642 \\
\hline & $I_{10 \ldots}$ & 1.061 & 0.990 & 0.994 & 1.012 & 1.014 & 0.689 & 0.698 \\
\hline \multirow{2}{*}{$\begin{array}{l}\text { Energomash-Project } \\
\text { Research and Production } \\
\text { Enterprise }\end{array}$} & $I_{p}$ & 0.779 & 0.957 & 1.534 & 0.989 & 1.065 & 0.399 & 0.425 \\
\hline & $\mathrm{I}_{\mathrm{FS}}$ & 1.111 & 1.005 & 0.984 & 1.019 & 1.030 & 0.393 & 0.405 \\
\hline
\end{tabular}

economic and political factors, which are related to the change of power in Ukraine, military actions in the Donbas region, rising energy prices, etc. However, the analysis and evaluation of such changes are not the purpose of this study. Therefore, let us focus only on the baseline scenario, which assumes an extrapolation of the existing dynamics over the next two years (Table 9).
Step 5. Thus, given the dynamics of group integral indicators, projected values of financial and economic security integral indicator for the studied enterprises up to 2020 have been calculated (Figure 1).

The calculation data show that if the dynamics of changes in the group integral indicators are maintained and the external challenges
A)

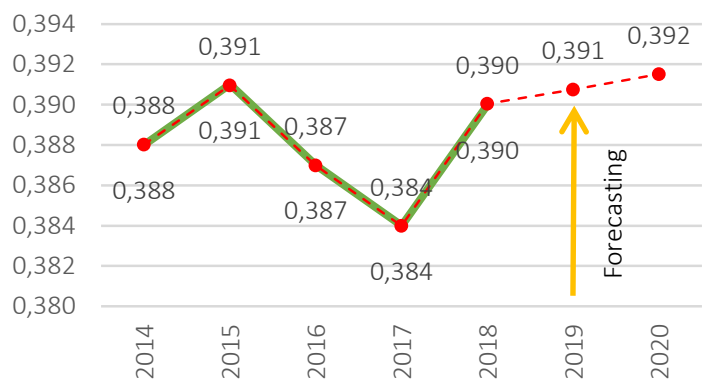

c)

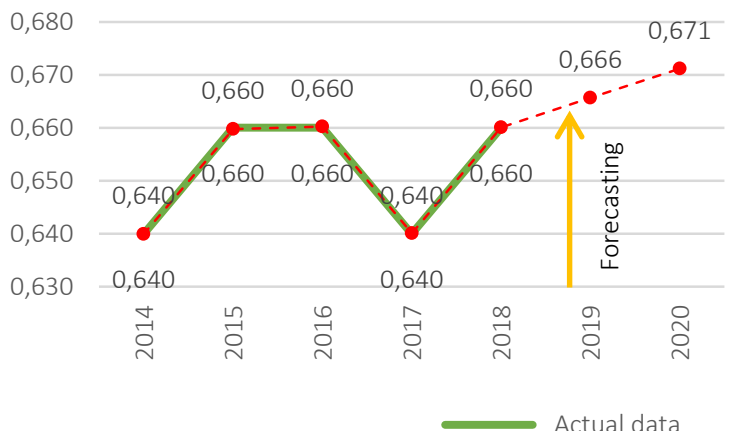

B)

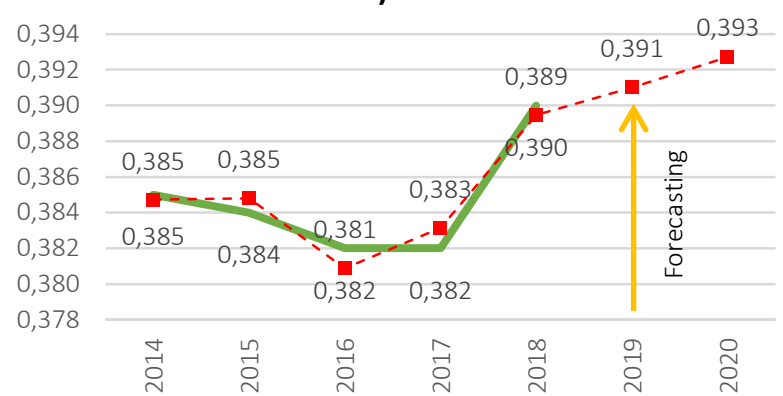

D)

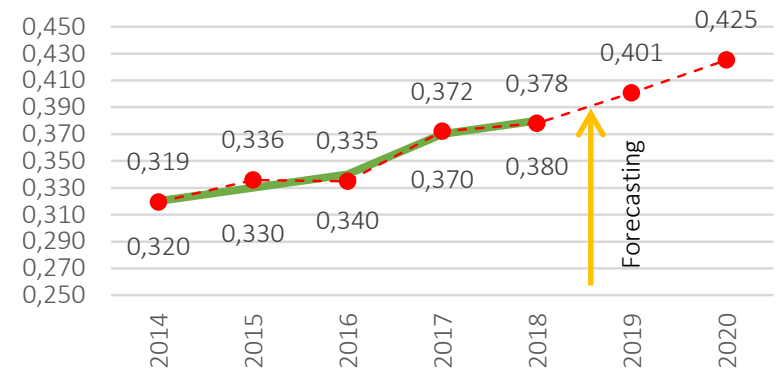

Note: A) Zaporizhzhia Mechanical Plant; B) Zaporozhye Heavy Crane-Building Plant; C) Berdianski Zhnyvarky; and D) Energomash-Project Research and Production Enterprise.

Figure 1. The forecast of financial and economic security integral indicator's value for enterprises under study 
are insignificant, then the integral financial and economic security indicator for all analyzed enterprises will increase in the next two years. Energomash-Project Research and Production Enterprise demonstrates the larg- est growth, $11.9 \%$, followed by the Berdianski Zhnyvarky company, 1.7\%; they are followed by Zaporozhye Heavy Crane-Building Plant, 0.7\%. Zaporizhzhia Mechanical Plant shows the lowest growth, $0.4 \%$.

\section{CONCLUSION}

The ability to detect financial status allows the company to support its sustainable development. Creating financial and economic security assessment system for a company that needs to be used at each enterprise to systematize the diagnostic process and improve their effectiveness deserves further development.

The study includes the parameters of an enterprise's financial status in the group of indicators (factors) that determine financial and economic security, since the condition of fixed assets becomes very important for them. Deterioration of fixed assets is one of the most problematic indicators of property valuation in Ukraine. Therefore, it is important when assessing the level of financial component in the economic security of the enterprise. Besides, the methodology should include the coefficient of updating fixed assets that characterizes the asset management policy of the enterprise.

Despite various internal and external challenges, industrial enterprises not only try to function at the level of previous periods, they also show motivation for development. The study showed that, regardless of the enterprise size, the level of financial and economic security can change due to the effectiveness of the management system. Also, assessing the level of financial and economic security allows identifying weaknesses and strengths of the activity, and, accordingly, determining effective management methods. The importance of this study is also in identifying general features of financial and economic security; providing opportunities for effective managerial decisions and comparative assessment of enterprises in one industry, both nationally and internationally. This allows us to use positive foreign experience in financial and economic security and to build an effective management model.

\section{REFERENCES}

1. Arefieva, O. V., \& Kuzenko, T. B. (2009). Ekonomichni osnovy formuvannia finansovoi skladovoi ekonomichnoi bezpeky [The economic basis for the formation of the financial component of economic security]. Aktualni problemy ekonomiky - Actual Problems of Economy, 1, 98-103. (In Ukrainian).

2. Berdianskiye Zhatki [Berdyansk Reapers]. (n.d.). Official website. Retrieved from http://zhatki.com/

3. Bondarenko, O. M., \& Levytskyy, B. V. (2015). Kompleksna otsinka finansovo-ekonomichnoi bezpeky: teoretychnyi ta praktychnyi aspekty [Complex assessment of financial and economic security: theoretical and practical aspects]. Efektyvna ekonomika - Effective Economy, 12. (In Ukrainian).
Retrieved from http://www.economy.nayka.com.ua/?op=1\&z=4701

4. Calof, J. (2016). Government sponsored competitive intelligence for regional and sectoral economic development: Canadian experiences. Journal of Intelligence Studies in Business, 6(1), 48-58. Retrieved from https://ojs.hh.se/ index.php/JISIB/article/view/142

5. Calof, J., Richards, G., \& Smith, J. (2015). Foresight, Competitive Intelligence and Business Analytics - Tools for Making Industrial Programmes More Efficient. Foresight-Russia, 9(1), 68-81.

6. Cherniak, G. M. (2015). Otsiniuvannia rivnia ekonomichnoi bezpeky enerhetychnykh pidpryiemstv $\mathrm{v}$ umovakh yevrointehratsii [Assessment of the level of economic security of energy enterprises in the context of European integration]. Ekonomichnyi visnyk Natsionalnoho tekhnichnoho universytetu Ukrainy "Kyivskyi politekhnichnyi instytut" Economic bulletin of the National Technical University of Ukraine "Kyiv Politechnic Institute", 12, 159-166. (In Ukrainian). Retrieved from http://nbuv.gov.ua/UJRN/ evntukpi_2015_12_26

7. Du Toit, A. S. A. (2015). Competitive intelligence research: An investigation of trends in the literature. Journal of Intelligence Studies in Business, 2, 14-21. Retrieved from https://ojs.hh.se/

8. Energomash NVP. (n.d.). Official website. Retrieved from http:// energo-mash.com.ual 
9. Fishburn, P. (1978). Teoriya poleznosti dlia priniatiya resheniy [Theory of utility for decisionmaking]. Moskow: Nauka. (In Russian).

10. Ganushchak, T. (2017). Dynamics of development of financial safety of the enterprise as a complex economic security of the state. Baltic Journal of Economic Studies, 3(4), 32-37.

11. Giannopoulos, G., Filippini, R., \& Schimmer, M. (2012). Risk assessment methodologies for critical infrastructure protection (Part I: A state of the Art) (70 p.). Luxembourg: Joint Research Centre of Institute for the Protection and Security of the Citizen.

12. Haralambides, H. E. (2002). Competition, excess capacity, and the pricing of port infrastructure. International. Journal of Maritime Economics, 4, 323-347.

13. Harrington, J. (1965). The desirability function. Industrial Quality Control, 21(10), 494-498.

14. Hryhoruk, P., Khrushch, N., \& Grygoruk, S. (2019, May 22-24). Model for assessment of the financial security level of the enterprise based on the desirability scale. CEUR Workshop Proceedings. 8th International Conference on Monitoring, Modeling and Management of Emergent Economy: Experimental Economics and Machine Learning for Prediction of Emergent Economy Dynamics, 2422, 169-180.

15. Ianioglo, A., \& Polajeva, T. (2016, May 12-13). Origin and definition of the category of economic security of enterprise. The 9th International Scientific Conference proceedings "Business and Management 2016". Vilnius, Lituania. Retrieved from http:// bm.vgtu.lt/index.php/verslas/2016/ paper/viewFile/47/47

16. Iershova, N. Yu., Tkachenko, M. O., Garkusha, V. O., Miroshnyk, O. Yu., \& Novak-Kalyayeva, L. M. (2019). Financial and credit activity: problems of theory and practice, 2(29), 142-149. https://doi.org/10.18371/fcaptp. v2i29.172365
17. Ignatov, A. (2019). Analysis of the dynamics of the European economic security in the conditions of a changing socioeconomic environment. New medit: Mediterranean Journal of Economics, Agriculture and Environment. Retrieved from https://newmedit.iamb.it/bup/ wp-content/uploads/2019/04/ nm1902b_Ignatov.pdf

18. Karanina, E. V., Ryazanova, O. A., Timin, A. N., \& Domracheva, L. P. (2019, April 2). Diagnostics and monitoring of economic entities security. E3S Web of Conferences, 91. https://doi.org/10.1051/e3sconf/20199108002

19. Karpenko, L., \& Voronzhak, P. (2017, November 30-DEC 01). Coordinates of the financial and economic security. 18th International Scientific Conference on International Relations Current Issues of World Economy and Politics. Smolenice, Slovakia.

20. Kondratenko, N., Kovalenko, L., \& Novikov, D. A. (2019). Methodical approach to assessing the level of construction company financial security. Financial and Credit Activity: Problems of Theory and Practice, 2(29), 287-295.

21. Korniienko, T. O. (2013). Metodyka otsinky rivnia ekonomichnoi bezpeky silskohospodarskykh pidpryiemstv [Methods of assessing the level of economic security of agricultural enterprises]. Stalyi rozvytok ekonomiky - Sustainable Economic Development, 4, 336-342. (In Ukrainian).

22. Kosny, M., \& Piotrowska, M. (2019, August 26). Assessment of economic security of households based on a scenario analysis, 7(3). IOP Conference Series: Earth and Environmental Science.

23. Kovalenko, D. I. \& Lehka, A. O. (2015). Mekhanizm zabezpechennia finansovoekonomichnoi bezpeky pidpryiemstva [The mechanism of ensuring the financial and economic security of the enterprise]. International Scientific Journal, 8, 118-122. (In Ukrainian). Retrieved from http://nbuv.gov.ua/ UJRN/mnj_2015_8_29
24. Kriuchko, L. S. (2013). Teoretychni zasady finansovoi bezpeky pidpryiemstva [The theoretical basis of financial security of the enterprise]. Investytsii: praktyka ta dosvid - Investment: Practice and Experience, 15, 49-52. (In Ukrainian).

25. Kudrytska, Zh. V. (2012). Systema upravlinnia finansovoiu bezpekoiu pidpryiemstva [The system of managing financial security of an enterprise]. Efektyvna ekonomika Effective Economy. (In Ukrainian). Retrieved from http://www. economy.nayka.com.ua

26. Kyrychenko, O. A., \& Kudria, I. V. (2009). Vdoskonalennia upravlinnia finansovoiu bezpekoiu pidpryiemstv v umovakh finansovoi kryzy [Improvement of financial security of the enterprise in crisis]. Investytsii: praktyka ta dosvid - Investment: Practice and Experience, 10, 22-26. (In Ukrainian).

27. Lewis, T. G. (2006). Critical infrastructure protection in homeland security: defending a networked nation (474 p.). John Wiley \& Sons, Inc.

28. Moiseienko, I. P., \& Marchenko, O. M. (2011). Upravlinnia finansovoekonomichnoiu bezpekoiu pidpryiemstva [Management of financial and economic security of an enterprise]. Lviv. (In Ukrainian).

29. Mulyk, Ya. I. (2013). Financial security of the enterprise: systematization of scientific views. Zbirnyk naukovykh prats VNAU, Ekonomichni nauky, 3(80), 195206. (In Ukrainian).

30. N. Venkatraman, \& Prescott, J. E. (1990). Environment-strategy coalignment: An empirical test of its performance implication. Strategic, Management, Sociology, 11(January 1), 1-23. Retrieved from https://onlinelibrary. wiley.com/doi/abs/10.1002/ smj.4250110102

31. Nikitina, A., \& Gorovyi, D. (2017). Vplyv zahroz funktsionalnykh skladovykh na riven ekonomichnoi bezpeky pidpryiemstv (na pryklaid pidpryiemstv avtomobilnoho transport [The influence of 
functional components threats on the level of economic security of companies (by the example of motor transport enterprises]. Marketynh i menedzhment innovatsii - Marketing and Management of Innovations, 3, 280-293. (In Ukrainian). https:// doi.org/10.21272/mmi.2017.3-26

32. Onishchenko, M. L., \& Siurkalo, B. I. (2018). Osoblyvosti mekhanizmu upravlinnia ekonomichnoiu bezpekoiu pidpryiemstva [Features of the control mechanism of the enterprise's economic security]. Ekonomika i suspilstvo - Economy and Society, 16, 446-452. (In Ukrainian). Retrieved from http:// economyandsociety.in.ua/journal/16_ukr/68.pdf

33. Roe, M. (2012). Maritime governance and policy-making. London: Springer.

34. Søilen, K. S. (2013). An overview of articles on Competitive Intelligence in JCIM and CIR. Journal of Intelligence Studies in Business, 1, 44-58. Retrieved from https://ojs.hh.se/

35. Sosnovska, O., \& Zhytar, M. (2019). Financial architecture as the base of the financial safety of the enterprise. Baltic Journal of Economic Studies, 4(4), 334-340. https://doi.org/10.30525/22560742/2018-4-4-334-340

36. Stolbov, V. F., \& Shapoval, H. M. (2013). Osoblyvosti upravlinnia systemoiu finansovoekonomichnoi bezpeky budivelnykh pidpruiemstv [Features management of the system of financial and economic security of construction enterprises]. Komunalne hospodarstvo mist - Municipal Utilities, 111, 103-108. (In Ukrainian).

37. Tamošiūnienè, R., \& Munteanu, C. (2015, July 2-3). Current research approaches to economic security. The $1^{\text {st }}$ International Conference on Business Management. Valencia, Spain. Retrieved from http:// ocs.editorial.upv.es/index.php/ ICBM/1ICBM/paper/viewFile/1537/723
38. Teneva, A., Nikolova-Alexieva, V., \& Yaneva A. (2018, June 11-14). Concept Model for Assessment of the Economic Security Level in Food Industry Enterprises. International Conference on High Technology for Sustainable Development (HiTech). Sofia, Bulgaria: The National Science \& Technology Center.

39. The Aspen Institute. (n.d.). Financial Security Program. Retrieved from https://www. aspeninstitute.org/programs/ financial-security-program/

40. Thompson, L. (1997). The benefits of separating rail infrastructure from operations. Retrieved from http://siteresources.worldbank. org/EXTFINANCIALSECTOR/Resources/2828841303327122200/135thomp.pdf

41. Vasilenko, M., \& Titova, N. (2019). Accounting policy the system of enterprise economic security. Amazonia Investiga, 8(22), 254260.

42. Vasilyev, O. V. \& Maita, V. I. (2013). Formuvannia systemy upravlinnia ekonomichnoiu bezpekoiu promyslovykh pidpryiemstv [Formation of economic security management system of industrial enterprises]. Ekonomichnyi Analiz - Economic Analysis, 2, 138-145. (In Ukrainian).

43. Vercellis, C. (2009). Business Intelligence: Data Mining and Optimization for Decision Making. John Wiley \& Sons.

44. Vergun, A. M., Nefedova, T. M., \& Tarasenko, I. O. (2015). Features of management of financial and economic security of the enterprise. International Scientific Journal, 2, 27-31. Retrieved from http://irbis-nbuv.gov.ua/ cgi-bin/irbis_nbuv/cgiirbis_64. exe? $\mathrm{C} 21 \mathrm{COM}=2 \& \mathrm{I} 21 \mathrm{DBN}=\mathrm{UJ}-$ RN\&P21DBN=UJRN\&IMAGE FILE_DOWNLOAD=1\&Image file_name $=$ PDF $/ \mathrm{mnj} \_2015 \_2 \_7$. pdf

45. Yaremko, Y., Shykova, L., \& Syvolap, L. (2019). Methods of evaluation and conceptualstrategic directions of economic security of agricultural enterprises.
Baltic Journal of Economic Studies, 4(5), 421-430. https://doi. org/10.30525/2256-0742/2018-45-421-430

46. Young S. D., \& O’Byrne, S. F. (2000). EVA and Value Based Management: A Practical Guide to Implementation (493 p.). NY: McGraw-Hill Professional.

47. Zaporozhcrane. (n.d.). Official website. Retrieved from http:// kran.zp.ua/

48. Zaporozhye Mechanical Plant. (n.d.). Official website. Retrieved from http://zmz-zp.com/ua/

49. Zhuravka, O. S., \& Bondarenko, Ye. K. (2012). Teoretychni aspekty formuvannia systemy finansovoi bezpeky pidpryiemstva [Theoretical aspects of the system of financial security of the enterprise]. Innovatsiina ekonomika - Innovative Economy, 4, 234-237. (In Ukrainian). 